\title{
PROFIL ANTROPOMETRI DAN SOMATOTIPE PADA ATLET BULUTANGKIS
}

\author{
Meutia Maulina* \\ Bagian Histologi, Fakultas Kedokteran, Universitas Malikussaleh \\ Lhokseumawe-Aceh, 24352, Indonesia \\ *Corresponding Author: dr.meuthya24@gmail.com
}

\begin{abstract}
Abstrak
Bulutangkis merupakan salah satu cabang olahraga yang sangat populer di Indonesia dan telah menjadi olahraga bergengsi andalan Indonesia. Prestasi atlet bulutangkis Indonesia terus mengalami kemunduran beberapa tahun terakhir, tidak hanya pada turnamen Piala Thomas, tetapi juga pada Piala Uber. Buruknya prestasi atlet bulutangkis ini memerlukan kajian terutama mengenai pembinaan atlet. Banyak teori yang diterapkan untuk mendapatkan calon atlet yang unggul, di antaranya pengukuran antropometri, pemeriksaan kesehatan statis dan dinamis serta somatotipe tubuh. Atlet bulutangkis idealnya memiliki berat badan ringan, basal metabolic index (BMI) rendah, tinggi badan sekitar $175 \mathrm{~cm}$, memiliki lipatan kulitbetis yang tipis serta lingkarbetis yang besar. Berdasarkan penilaian somatotipe, atlet bulutangkis cenderung ektomorf sehingga memiliki daya tahan, kelenturan dan kelincahan yang baik. Berbagai faktor mempunyai peran penting dalam menentukan tingkat performa dalam suatu permainan dan olahraga. Namun, faktor biomekanik, psikologis dan parameter fisiologis menjadi faktor penting penentu keberhasilan seorang atlet dalam mencapai performa maksimal sehingga dapat membuahkan prestasi yang baik.
\end{abstract}

Kata Kunci: atlet bulutangkis; profil antropometri; somatotipe 


\title{
ANTHROPOMETRY PROFILE AND SOMATOTYPE OF BADMINTON ATHLETES
}

\begin{abstract}
Badminton is one ofthe sportwhich is very popular in Indonesia and has become a prestigioussportmainstay of Indonesia.The achievements ofIndonesian badminton athletes continued to decline lately, not onlyon the Thomas Cup, but also on the Uber Cup. Poor achievement of badminton athletes had to be assessed especially on the athletes coaching. Many theories were applied to obtain superior athletes candidates, including anthropometric measurements, static and dynamic medical examinations and body somatotype. Badminton athletes ideally had a light weight,low basal metabolic index (BMI), height about $175 \mathrm{~cm}$, had a thin calf skin folds and a large calf circumference. Based on somatotype assessments, badminton athletes tend ectomorphy so hadgood durability, flexibility and agility. Various factors had an important role in determining the level of performance in a game and exercise. However, biomechanical factors, psychological and physiological parameters were an important factors determining the success of athletes to achieved maximum performance due to reached good achievements.
\end{abstract}

Keywors: badminton athletes; antrhopometry profile; somatotype 


\section{PENDAHULUAN}

Bulutangkis merupakan cabang olahraga yang dapat dimainkan dengan mudah oleh semua orang dari berbagai kalangan dan usia. Olahraga ini sangat digemari masyarakat karena selain menyehatkan juga dapat menimbulkan kegembiraan dan kepuasan tersendiri bagi pemainnya ${ }^{1}$. Bulutangkis merupakan salah satu cabang olahraga yang sangat populer di Indonesia dan telah menjadi olahraga bergengsi yang menjadi andalan Indonesia di mata dunia. Banyak klub olahraga ini yang berdiri dan telah mencetak banyak pemain dunia seperti Susi Susanti, Alan Budi Kusuma dan Taufik Hidayat yang telah mengharumkan nama Indonesia di forum internasional.

Dewasa ini prestasi atlet bulutangkis Indonesia terus mengalami kemunduran. Hal ini terbukti dengan kegagalan Tim Thomas Indonesia mempersembahkan kemenangan pada turnamen Piala Thomas tahun 2014 yang diselenggrakan di New Delhi, India setelah dikalahkan oleh Tim Malaysia di babak semifinal. Tim Uber Indonesia juga menambah sejarah panjang kegagalan setelah terakhir kali Piala Uber direbut oleh Tim Indonesia di Hongkong pada tahun 1996. Tim Indonesia hanya sampai pada babak semi final dikalahkan oleh China dan Korea Selatan pada perebutan tahun 1998, 2000 dan 2002. Tragisnya pada perebutan tahun 2004 yang dilaksanakan diIndonesia, Tim Indonesia justru hanya bertahan pada babak perempat final setelah dikalahkan oleh Tim Uber Korea Selatan. Pada perebutan tahun 2014 di New Delhi, Tim Uber Indonesia kembali gagal setelah dikalahkan oleh Tim tuan rumah di babak perempat final. Melihat kondisi prestasi Indonesia yang terus merosot ini sudah saatnya Indonesia berbenah dan mengevaluasi diri terhadap berbagai aspek yang menjadi faktor penting penyebab kegagalan para atlet terutama dalam hal-hal yang bertujuan untuk mengembalikan prestasi olahraga Indonesia khususnya cabang bulutangkis di masa mendatang 2 .

Buruknya prestasi olahraga di Indonesia terutama bulutangkis memerlukan kajian menyeluruh terutama mengenai pembinaan olahraga yang meliputi tahapan pemassalan, pembibitan dan pemanduan bakat, pembinaan intensif dan pencapaian prestasi puncak. Terkait dengan rangkaian utuh sistem pembinaan tersebut, maka identifikasi dan rekrutmen calon atlet berbakat merupakan langkah yang patut diperhitungkan di tengah keterpurukan prestasi olahraga nasional ${ }^{3,4}$.

Upaya untuk meningkatkan prestasi olahraga bagi seorang atlet tidak hanya berdasarkan pada minat yang tinggi saja, tetapi juga harus memenuhi syarat-syarat somatik dan umur yang optimum. Banyak ahli bependapat bahwa prestasi seseorang tergantung pada ukuran, bentuk, proporsi, komposisi, maturasi dan fungsi organ ${ }^{5}$.

Penelitian mengenai olahraga yang menyangkut aspek antropometri dan somatotipe atlet masih sangat sedikit di Indonesia. Padahal penelitian ini mempunyai peran penting karena selain dapat mengetahui ciri-ciri fisik atlet, juga dapat dipakai sebagai salah satu bahan masukan dalam pembibitan atlet dan peningkatan prestasi olahraga ${ }^{5}$.

\section{Pembahasan \\ Profil Antropometri}

Antropometri adalah pengukuran tubuh manusia yaitu pengukuran panjang, lebar, diameter, lingkar, menghitung rasio dan proporsi yang didasarkan pada dua atau lebih pengukuran, sehingga dapat digunakan untuk mengidentifikasi bentuk, ukuran,serta topografi tubuh. Informasi dasar tentang struktur tubuh manusia dapat digunakan untuk memperkirakan gaya yang bekerja pada sendi dan jaringan tubuh serta kekuatan yang dihasilkan' ${ }^{6}$. 
Antropometri banyak diterapkan dalam bidang olahraga. Salah satu aspek penting dalam pencapaian prestasi olahraga adalah stabilisasi berat badan pada puncak penampilan. Atlet secara umum membutuhkan komposisi tubuh yang tepat, tidak berat dan tidak terlalu banyak lemak. Pengukuran antropometri dan somatotipe diperlukan untuk menentukan kondisi fisik atlet. Studi mengenai terapan antropometri pada bidang olahraga akan menyinggung hal proporsi badan, performance (optimal, minimal dan maksimal berat badan) dan biomekanik ${ }^{7}$.

Atlet bulutangkis lebih banyak menggunakan kemahiran lengan dan tangan dalam permainannya. Pada olahraga ini tidak ada kontak fisik, sehingga berat badan yang rendah, tungkai yang panjang dan tubuh yang langsing lebih menguntungkan karena memungkinkan jangkauan yang jauh.Tinggi badan pemain bulutangkis yang baik adalah sekitar $175 \mathrm{~cm}$ dengan perkiraan tinggi bahu setinggi jaring (antara 152,5-155,0 cm) sehingga memungkinkan variasi pukulan terbanyak. Pemain akan mengalami kesukaran menerima bola rendahbila badan terlalu tinggi karena bola rendah akan menyebabkan tubuh terlalu tinggi membungkuk atau tungkai fleksi ${ }^{5}$.

Berdasarkan penelitian Rahmawati dkk., di Yogyakarta tahun 1994 dan 1995 pada 19 orang atlet bulutangkis laki-laki usia antara 16 - 27 tahun, diperoleh hasil bahwa atlet bulutangkis mempunyai tinggi badan yang paling pendek, berat badan paling ringan, Basal Metabolic Index (BMI) rendah, keempat anggota gerak paling kecil dan ramping, serta memiliki lipatan kulit Ztriseps yang paling besar bila dibandingkan dengan atlet sepak bola dan bola voli ${ }^{9}$.

Berdasarkan penelitian yang dilakukan oleh Yasin dkk.,pada 30 atlet bulutangkis dan tenis, ditemukan perbedaan statistik yang signifikan dalam ukuran diameter betis antara atlet bultangkis dan tenis.
Lingkar betis atlet bulutangkis lebih besar dan lipatan kulit betis lebih tipis dari atlet tenis. Hal ini menunjukkan bahwa kepadatan otot atlet bulutangkis lebih besar pada bagian betis. Penyebab dari keadaan ini diduga berhubungan dengan aktvitas melompat dalam bermainbulutangkis dan gerakan kontinu pada ujung jari kaki dari pemain bulutangkis ditempat yang lebih sempit. Menurut ukuran diameter, teramati bahwa pemain tenis memiliki bahu yang lebih besar dan pinggang ramping serta terdapat perbedaan yang signifikan dalam biacromical, bitrochanteric dan femoralis diameter epicondular antara dua cabang olahraga ini ${ }^{1}$.

\section{Somatotipe}

Postur adalah sebutan yang lazim digunakan untuk menyebut bentuk atau tampakan tubuh dengan memperhatikan kontur tubuh, proporsi, dan komposisi. Salah satu metode yang paling sering digunakan untuk studi karakteristik proporsi dan morfologi tubuh adalah somatotyping. Somatotyping adalah sistem untuk mengklasifikasi tipe tubuh dalam 3 kategori, yaitu endomorf (endomorphy), mesomorf (mesomorphy) dan ektomorf (ectomorphy). Endomorf berhubungan dengan lemak bawah kulit, mesomorf berhubungan dengan sistem muskularis, sedangkan ektomorf berhubungan dengan tinggi dan berat badan 6,8 .

Atlet cenderung lebih mesomorfik, kecuali untuk atlet olahraga tertentu seperti bulutangkis dan atlet lari jarak jauh yang cenderung ektomorfik. Atlet juga biasanya lebih tinggi dari pada rata-rata populasi. Berbagai penelitian dewasa ini menggunakan metode carter anthropometric somatotyping, menunjukkan bahwa atlet olahraga tertentu dikategorikan sesuai dengan tempat-tempat unik pada bagan somatotipe ${ }^{6}$.

Berdasarkan penelitian yang dilakukan oleh Rahmawati dkk., di Yogyakarta tahun 
1994 dan 1995 pada 19 orang atlet bulutangkis laki-laki usia antara 16 - 27 tahun, didapatkan hubungan yang signifikan antara jenis olahraga dan kategori somatotipe. Sebagian besar atlet bulutangkis dalam penelitian tersebut (32\%) berada pada kategori sentral, sedangkan $16 \%$ lainnya berada pada kategori ektomorf7. Pada penelitian lainnya mengenai ukuran antropometri pada atlet bulutangkis di Yogyakarta didapatkan distribusi somatotipe atlet bulutangkis sebagian besar terletak di daerah ekto-mesomorf dan endoektomorf 5 .

\section{Pengaruh Profil Antropometri dan Somatotipe Atlet terhadap Pencapaian Prestasi}

Pencapaian prestasi dan kemenangan pada pertandingan olahraga bulutangkis dipengaruhi oleh beberapa faktor, yaitu tingkat kebugaran, ketrampilan, strategi dan taktik. Performa dan kinerja atlet di lapangan dipengaruhi oleh beberapa variabel yang kompleks, meliputi faktor fisik (kondisi umum dan spesifik), psikologis (kecerdasan, kepribadian dan motivasi) dan faktor sosiologis dan karakteristik fisik (morfologi tubuh, antropometri dan komposisi tubuh). Berbagai faktor mempunyai peran penting dalam menentukan tingkat performa dalam suatu permainan dan olahraga. Namun, faktor biomekanik, psikologis dan parameter fisiologis menjadi faktor penting penentu keberhasilan seorang atlet dalam mencapai performa maksimal ${ }^{8}$.Selain itu, aspek usia juga mempunyai peran penting dalam pencapaian prestasi. Aspek usia meliputi usia kronologis maupun usia kecerdasan ${ }^{3}$.

Walaupun bukan satu-satunya faktor yang menentukan kemenangan dalam suatu pertandingan, namun keunggulan postur tubuh jugaikut berperan dalam hal efisiensi tenaga. Postur tubuh yang lebih tinggi memungkinkan seorang atlet menghemat tenaga lebih baik jika dibandingkan dengan postur tubuh yang pendek. Postur yang lebih tinggi akan memudahkan menjangkau bola dengan segala posisi. Dari segi energi juga sangat menguntungkan karena efisiensi tenaga dapat diatur dengan baik disesuaikan dengan kebutuhan jika dibandingkan dengan postur tubuh yang lebih pendek ${ }^{2}$.

Tinggi badan (TB) seorang atlet bulutangkis merupakan kelebihan atau modal dalam melakukan serangan dan bertahan. Kelebihan dalam menyerang seorang atlet yang berpostur tinggi mempunyai kecepatan dalam melakukan serangan seperti melakukan smes yang tajam, drop shot yang mematikan, lop panjang yang relatif lama, dan strategi permainan netting yang halus ${ }^{2}$.

Berat badan (BB) dan BMI juga merupakan faktor penting bagi performa atlet sehingga dapat memperbesar kemungkinan pencapaian kemenangan. Bila BB dan BMI seorang atlet kurang ideal, seperti kelebihan berat badan dengan somatotipe cenderung endomorf, akan mempengaruhi motorikpara atlet yaitu berkurangnya kelincahan, kekuatan maupun daya tahan, pukulan menjadi tidak akurat dan kelelahan meningkat akibat akumulasi asam laktat dalam otot yang besar. Hal ini akan menyebabkan terjadinya kesalahan demi kesalahan baik kesalahan sendiri (unporce error) maupun karena lawan. Kesalahan yang sering terjadi seperti bola menyangkut di net, bola melebar, maupun memanjang, pukulan yang tidak terarah, permainan mudah didikte, mudah terbaca sehingga bola-bola yang dikembalikan mudah dimatikan oleh lawan ${ }^{2}$

\section{Kesimpulan}

1. Atlet bulutangkis memiliki TB sekitar $175 \mathrm{~cm}, \mathrm{BB}$ ringan, BMI rendah, lipatan kulit betis tipis dan lingkar betis yang besar. 
2. Atlet bulutangkis cenderung ektomorf, yaitu bentuk tubuh ramping dan langsing dengan lengan dan tungkai yang jenjang, tubuh tidak berlemak dan otot-otot tampak liat, terutama otot bagian lengan dan tungkai.

3. Faktor biomekanik, psikologis dan parameter fisiologis menjadi faktor penting penentu keberhasilan seorang atlet dalam mencapai performa maksimal sehingga dapat membuahkan prestasi yang baik.

\section{DAFTAR PUSTAKA}

1. Yasin A, Omer S, Ibrahim Y, Akif BM, Cengiz A. Comparison of some snthropometric characteristic of elite badminton and tennis players. Science, Movement and Health 2010;(2):400-405.

2. Tangkudung J. Profil tinggi badan, berat badan dan indeks massa tubuh (IMT) atlet Piala Thomas dan Uber. Jurnal Iptek Olahraga 2006;8(3):192-205.

3. Wahjoedi. Aspek psikofisik dalam rekrutmen atlet di lingkungan TNI/POLRI. Jurnal Iptek Olahraga 2007;9(3):202-214.
4. Mansur, MS., Pemanduan Bakat Olah Raga, Fakultas Ilmu keolahragaan, Universitas negeri Yogyakarta, 2011.

5. Rahmawati NT. Beberapa ukuran antropometri pada atlet sepakbola dan bulutangkis di Yogyakarta. Berkala Ilmu Kedokteran 1996;28(2):72-78.

6. Adrian MJ, Cooper JM. Biomechanics of human movement. 2nd Ed. USA: Brown and Bencmark Publishers, 1995.

7. Glinka J, Artaria MD, Koesbardiati T.Metode pengukuran manusia. Surabaya: Airlangga University Press, 2008.

8. Rahmawati NT, Budiharjo S, Ashizawa K. Somatotype of young male athletes and non-athletes students in Yogyakarta, Indonesia. Anthropological Science 2007;115:1-7.

9. Mohammad A. Physical characteristics and level of performance in badminton: a relationship study. Journal of Education and Practice 2011; 2(5):6-9.

10. etd.repository.ugm.ac.id/../76672/../S12014-299666-introduction.pdf 